\title{
Seed quality parameters (Germination percentage and seedling vigor index) of rabi sorghum seeds influenced by rice weevil infestation
}

\begin{abstract}
The genotypes KMJ 1(99.50\%), RSJ 1(97.50\%), CSV 216R(96.00\%) and AKJ $1(94.50 \%)$ have shown maximum germination percentage under uninfested condition and also the same genotypes performed well by showing $(100.00 \%),(93.00 \%)$ and $(91.50 \%)$ highest germination percentage respectively even after four months infestation period. However under uninfested condition the genotypes Phule Revati (73.00\%), Phule Vasudha (73.50\%), 5-4-1(80.00\%) and CSV 22(82.50\%) have recorded significantly lower germination percentages where as under infested condition BR 33(54.50\%), 5-4-1(56.50\%), BJV 44(58.00\%), CSV 22(61.00\%), SMJ $1(66.00 \%)$ and CSV $18(67.00 \%)$ have recorded minimum germination. The maximum seedling vigor index was recorded in M 35-1(3448) in both uninfested and (2649) infested conditions and at the same there was reduction in germination by 0.54 per cent for every one per cent increase in population buildup of rice weevils and the values are significant at 5 per cent.
\end{abstract}

Keywords: sitophilus oryzae, rabi sorghum genotypes, germination, seedling vigor infested and uninfested condition
Volume 4 Issue 6 - 2018

Pradeep

Department of Food and Public Distribution, India

Correspondence: Pradeep, Technical Officer (S\&R), IGMRI, Hapur, Ministry of CA, Food \& PD, D/o of Food and Public Distribution, Govt. of India, India, Tel 09449977 380, Email pradigouda627@gmail.com

Received: October 27, 2018 | Published: November 26, 2018

\section{Introduction}

Sorghum (Sorghum bicolor (L.) Moench) is an important food and fodder crop of India and which ranks fourth after wheat, rice and maize and serving as a staple food for millions of people particularly in semi-arid tropics of the world. Rice weevil is economically important storage pest on sorghum and other cereals in tropics and sub-tropics of the world. Rice weevil infestation alone resulted in sorghum grain loss of 61.3 per cent over a period of five months. ${ }^{1}$

Major loss of food grains in storage is contributed by two internal primary feeder's viz., rice weevil (Sitophilus oryzae Linn.) and lesser grain borer (Rhizopertha dominica Fab.). Rice weevil (Sitophilus oryzae Linn.) [Curculionidae, Coleoptera.] being a internal feeder, the grubs feed on the internal contents of the seed or grain without notice until the adult weevil emerges out from the grain, which leads the grains in deterring the quality as well as reducing the vital processes of the seed such as germination etc,. Germination and seedling vigor are two important parameters which decide the quality of the seeds.

It is well established fact that lot of efforts should be put for the production of "every single grain" but this is of no use if the produced grains are not saved, which recalls the proverb "a grain saved is a grain equally produced". This adage depends mainly on how best we protect the quality of grains during storage. Loss of grains stored as seed and future food of the country is to the tune of 7-8 per cent accounting to major share of economic loss worth Rs. 600-700crores. At the same time scientists are putting their efforts and attempting to find ways and means to reduce losses in storage due to stored pests. Farmers retain 60 to 70 per cent of their agricultural produce for seed purpose, home consumption and for sale due to storage pest infestation. ${ }^{2}$

\section{Material and methods}

Studies on the seed quality parameters (germination percentage and seedling vigor index) of rabi sorghum seeds influenced by rice weevil infestation were carried out during 2012-13 at the Department of Agricultural Entomology, College of Agriculture, Bijapur, Karnataka. Seed quality parameters were observed in rabi sorghum for experimentation under CRD to evaluate the effect of rice weevil infestation.

Twenty rabi sorghum genotypes, inclusive of some of the released hybrids, resistant and susceptible checks, good land races and restorer lines were selected for the studies. Five hundred grams of seed samples of above 20 sorghum genotypes were collected during rabi 2011-2012 to study per cent grain damage against $S$. oryzae under laboratory conditions. Freshly harvested seeds were obtained from All India Coordinated Sorghum Improvement Project (AICSIP) situated at the Regional Agricultural Research Station, Bijapur and Agricultural Research Station, Hebballi, Dharwad.

Sound, unaffected grains of each genotype were kept in hot air oven for six hours at $42^{\circ} \mathrm{C}$ in order to eliminate the insect pest infestation. The moisture content of seeds was less than 12 per cent. Seeds of each variety/genotypes weighing $50 \mathrm{~g}$ were kept in glass containers of $250 \mathrm{~g}$ capacity separately for the investigation of grain damage by the pest.

Five pairs of five days old adult insects were introduced in each bottle and tops were kept covered with muslin cloth and fastened with rubber band. These were kept in two replications for observations up to 120 days. Each bottle was examined periodically at monthly intervals to note the per cent damaged grains. The data were subjected to statistical analysis. The data in percentages were subjected to 
angular transformations before statistical analysis. The seed quality test was conducted for infested and uniinfested seeds separately by adopting following methods (Table 1).

Table I List of different rabi Sorghum genotypes imposed in treatments used for screening studies

\begin{tabular}{|c|c|}
\hline SI. No. & Genotype \\
\hline $\mathrm{I}$. & M 35-I \\
\hline 2. & CSV 18 \\
\hline 3. & Phule Chitra \\
\hline 4. & PKV Kranti \\
\hline 5. & Parabani Joti \\
\hline 6. & Phule Vasudha \\
\hline 7. & Phule Revati \\
\hline 8. & 5-4-I (Muguti) \\
\hline 9. & BR 33 \\
\hline 10. & BJV 44 \\
\hline II. & BRJ 204 \\
\hline 12. & KMJ I \\
\hline 13. & SMJ I \\
\hline 14. & AKJ I \\
\hline 15. & RSJ I \\
\hline 16. & CSV 22 \\
\hline 17. & CSV $216 R$ \\
\hline 18. & SPV 2033 \\
\hline 19. & DSV 4 \\
\hline 20. & DSV 5 \\
\hline
\end{tabular}

\section{Seed quality parameters}

\section{Standard Germination test (\%)}

Germination test was conducted as per the International Seed Testing Association (ISTA) ${ }^{3}$ procedure by adopting between paper method in a germinator maintained at $25-30^{\circ} \mathrm{C}$ and $95 \pm 3$ per cent relative humidity in three replications each of 100seeds. The first count on fourth day and second count on tenth day of germination for normal seedling was made and expressed as germination percentage.

\section{Seedling length $(\mathrm{cm})$}

Five normal seedlings from the germination test were randomly selected for measurement of seedling length on tenth day. The seedling length was measured from the collar region to the tip of the primary leaf. The mean seedling length was expressed in centimeters.

\section{Seedling vigor index (VI)}

Seedling vigor index was calculated by using the below formula as suggested by Abdul-Baki et al., ${ }^{4}$ expressed in whole number.

Vigor Index (VI) = Germination (\%) x Seedling length $(\mathrm{cm})$

\section{Results and discussion}

\section{Seed germination percentage of sorghum genotypes in uninfested condition}

The seed quality parameters are significantly influenced by sorghum genotypes infested by Sitophilus oryzae are presented in Table 2, Figure 1A the seed germination of sorghum genotypes Phule Revati (73.00\%), Phule Vasudha (73.50\%), 5-4-1(80.00\%) and CSV $22(82.50 \%)$ have recorded significantly lower germination percentage with significantly differing each other, where as KMJ 1(99.50\%), RSJ 1(97.50\%), CSV 216R(96.00\%) and AKJ 1(94.50\%) have shown maximum germination percentage and are significantly differing each other. Germination per cent of the other genotypes were in the range between 83.50 per cent and 92.50 per cent when all maintained excluding infestation from rice weevil at 120days after storage.

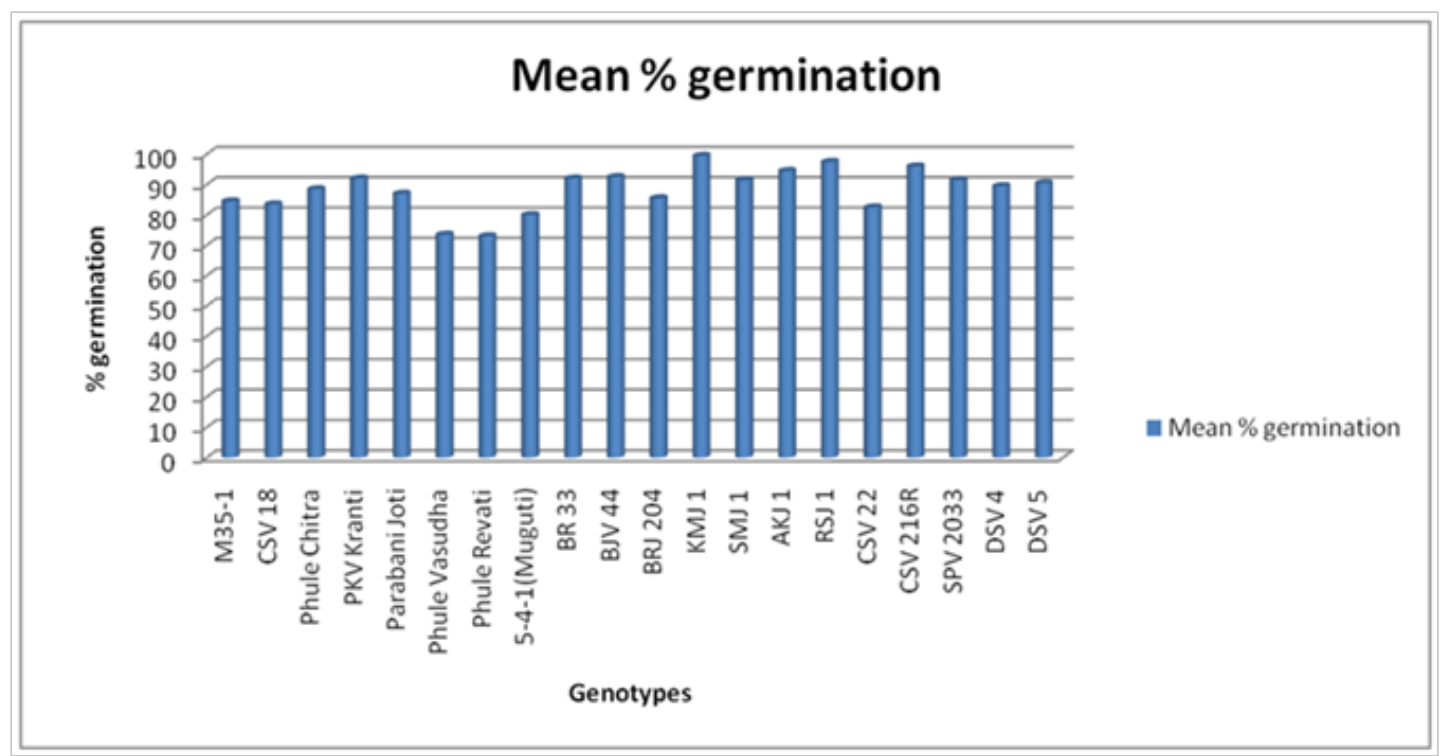

Figure IA Seed quality as influenced by different genotypes in sorghum, per cent germination.

(Undamaged condition) 
Table 2 Seed quality parameters as influenced by different genotypes in sorghum (Uninfested condition)

\begin{tabular}{|c|c|c|c|c|c|}
\hline $\begin{array}{l}\text { Sl. } \\
\text { No. }\end{array}$ & $\begin{array}{l}\text { Varieties/ } \\
\text { Genotypes }\end{array}$ & $\begin{array}{l}\text { First count mean } \% \\
\text { germination }\end{array}$ & $\begin{array}{l}\text { Second count mean } \% \\
\text { germination }\end{array}$ & $\begin{array}{l}\text { Seedling } \\
\text { length(cm) }\end{array}$ & $\begin{array}{l}\text { Seedling vigor index based on } \\
\text { seedling length }\end{array}$ \\
\hline I. & M 35-I & $5.00(12.93)$ & $84.50(66.85)$ & 40.8 & 3448 \\
\hline 2. & CSV 18 & $4.00(11.54)$ & $83.50(66.07)$ & 20 & 1670 \\
\hline 3. & Phule Chitra & $26.00(30.67)$ & $88.50(70.21)$ & 23 & 2036 \\
\hline 4. & PKV Kranti & $58.00(49.63)$ & $92.00(73.61)$ & 29.8 & 2742 \\
\hline 5. & Parabani Joti & $22.00(27.99)$ & $87.00(68.90)$ & 21.9 & 1905 \\
\hline 6. & Phule Vasudha & $17.00(24.36)$ & $73.50(59.05)$ & 31.5 & 2315 \\
\hline 7. & Phule Revati & $7.50(15.90)$ & $73.00(58.72)$ & 29.4 & 2146 \\
\hline 8. & 5-4-I (Muguti) & $6.00(14.19)$ & $80.00(63.47)$ & 26.6 & 2128 \\
\hline 9. & BR 33 & $7.00(15.35)$ & $92.00(73.61)$ & 28.2 & 2594 \\
\hline 10. & BJV 44 & $33.00(35.08)$ & $92.50(74.14)$ & 32.1 & 2969 \\
\hline II. & BRJ 204 & $3.00(9.98)$ & $85.50(67.65)$ & 21.6 & 1847 \\
\hline 12. & KMJ I & $99.00(84.30)$ & $99.50(85.99)$ & 30.3 & 3015 \\
\hline 13. & SMJ I & $10.50(18.92)$ & $91.50(73.09)$ & 27.3 & 2498 \\
\hline 14. & $A K J I$ & $45.50(42.44)$ & $94.50(76.48)$ & 25.3 & 2391 \\
\hline 15. & RSJ I & $47.50(43.59)$ & $97.50(80.94)$ & 26.6 & 2594 \\
\hline 16. & CSV 22 & $\mid 3.50(2 \mid .57)$ & $82.50(65.30)$ & 22.4 & 1848 \\
\hline 17. & CSV $216 R$ & $40.50(39.54)$ & $96.00(78.50)$ & 29.6 & 2842 \\
\hline 18. & SPV 2033 & II.00(I9.38) & $91.50(73.09)$ & 26.2 & 2397 \\
\hline 19. & DSV 4 & $18.50(25.49)$ & $89.50(71.13)$ & 24.5 & 2193 \\
\hline \multirow[t]{4}{*}{20.} & DSV 5 & $30.00(33.23)$ & $90.50(72.08)$ & 21.8 & 1973 \\
\hline & SEm \pm & 0.11 & 0.08 & 0.05 & 0.39 \\
\hline & C.D.(I\%) & 0.45 & 0.34 & 0.19 & 1.56 \\
\hline & C.V.(\%) & 0.55 & 0.17 & 0.24 & 0.023 \\
\hline
\end{tabular}

*figures in the parenthesis are arcsine transformed values

Seedling vigor index of sorghum genotypes in uninfested condition

Among the genotypes at 120days after storage the maximum seedling vigor index Table 2, Figure 1B was recorded in M 351(3448), at the same time minimum was noticed in the genotype BRJ 204 (1847) and rest of the genotypes showed the seedling vigor index between the range 1848 and 3015 .

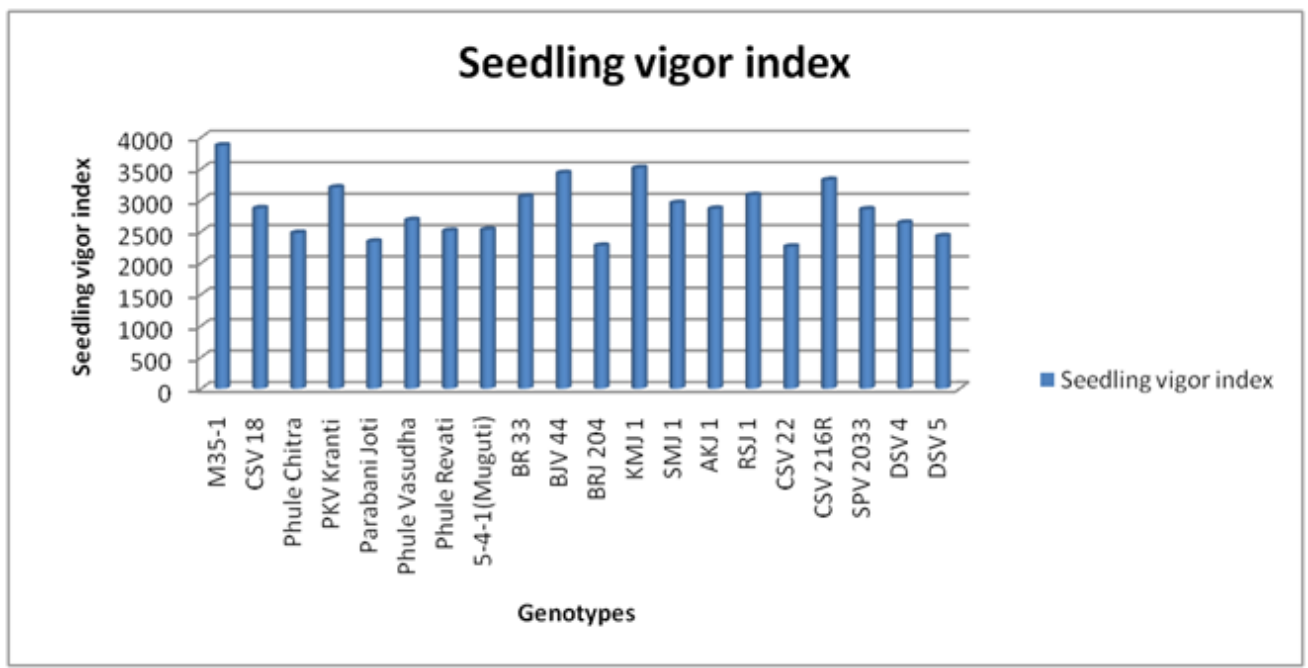

Figure IB Seed quality as influenced by different genotypes in sorghum, seedling vigor index.

(Undamaged condition)

Citation: Pradeep. Seed quality parameters (Germination percentage and seedling vigor index) of rabi sorghum seeds influenced by rice weevil infestation. MOJ Toxicol. 20I8;4(6):39I-396. DOI: I0.15406/mojt.2018.04.00I35 
Seed germination percentage and seedling vigor index of sorghum in infested condition at I20days after storage

From the Table 3, (Figure 2A \& 2B) the genotypes BR 33(54.50\%), 5-4-1(56.50\%), BJV 44(58.00\%), CSV 22(61.00\%), SMJ 1 (66.00\%) and CSV 18(67.00\%) have recorded minimum germination when exposed to the rice weevil infestation for a period of four months and are significantly differing each other. While KMJ 1(100.00\%), RSJ 1(93.00\%) and CSV 216R(91.50\%) have recorded highest germination percentages even after infestation period of four months. Excluding above rest of the genotypes have shown germination per cent between the range 69.00 per cent to 81.00 per cent.

Table 3 Seed quality parameters as influenced by different genotypes infested by rice weevil in sorghum (Infested condition).

\begin{tabular}{|c|c|c|c|c|c|}
\hline $\begin{array}{l}\text { Sl. } \\
\text { No. }\end{array}$ & $\begin{array}{l}\text { Varieties/ } \\
\text { Genotypes }\end{array}$ & $\begin{array}{l}\text { First count mean } \% \\
\text { germination }\end{array}$ & $\begin{array}{l}\text { Second count mean \% } \\
\text { germination }\end{array}$ & $\begin{array}{l}\text { Seedling } \\
\text { length }(\mathrm{cm})\end{array}$ & $\begin{array}{l}\text { Seedling vigor index based on } \\
\text { seedling length }\end{array}$ \\
\hline I. & M 35-I & $0.00(0.00)$ & $74.00(59.37)$ & 35.8 & 2649 \\
\hline 2. & CSV 18 & $1.00(5.74)$ & $67.00(54.97)$ & 15 & 1005 \\
\hline 3. & Phule Chitra & $22.00(27.99)$ & $76.00(60.70)$ & 18 & 1368 \\
\hline 4. & PKV Kranti & $50.00(45.02)$ & $75.00(60.03)$ & 24.8 & 1860 \\
\hline 5. & Parabani Joti & $28.00(31.96)$ & $69.00(56.20)$ & 16.9 & 1166 \\
\hline 6. & Phule Vasudha & $24.50(29.68)$ & $75.50(60.36)$ & 26.5 & 2001 \\
\hline 7. & Phule Revati & $5.50(\mid 3.57)$ & $69.00(56.20)$ & 24.4 & 1684 \\
\hline 8. & 5-4-I (Muguti) & $5.00(12.93)$ & $56.50(48.76)$ & 21.6 & 1220 \\
\hline 9. & BR 33 & $6.50(14.78)$ & $54.50(47.61)$ & 23.2 & 1264 \\
\hline 10. & BJV 44 & $1.00(5.74)$ & $58.00(49.63)$ & 27.1 & 1572 \\
\hline 11. & BRJ 204 & $38.50(38.37)$ & $81.00(64.19)$ & 16.6 & 1345 \\
\hline 12. & KMJ I & $100.00(90.05)$ & $100.00(90.05)$ & 25.3 & 2530 \\
\hline 13. & SMJ I & $12.50(20.72)$ & $66.00(54.36)$ & 22.3 & 1472 \\
\hline 14. & $\mathrm{AKJ} I$ & $31.00(33.85)$ & $81.00(64.19)$ & 20.3 & 1644 \\
\hline 15. & RSJ I & $40.00(39.25)$ & $93.00(74.70)$ & 21.6 & 2009 \\
\hline 16. & CSV 22 & $9.50(17.96)$ & $61.00(51.38)$ & 17.4 & 1061 \\
\hline 17. & CSV 216R & $41.50(40.13)$ & $91.50(73.09)$ & 24.6 & 2251 \\
\hline 18. & SPV 2033 & $3.00(9.98)$ & $69.00(56.20)$ & 21.2 & 1463 \\
\hline 19. & DSV 4 & $22.50(28.33)$ & $72.50(58.40)$ & 19.5 & 1414 \\
\hline \multirow[t]{4}{*}{20.} & DSV 5 & $19.50(26.22)$ & $69.50(56.5 \mathrm{I})$ & 16.8 & 1168 \\
\hline & SEm \pm & 0.07 & 0.13 & 0.01 & 25.67 \\
\hline & C.D.(I\%) & 0.28 & 0.52 & 0.04 & 103.3 \\
\hline & C.V.(\%) & 0.37 & 0.3 & 0.07 & 2.26 \\
\hline
\end{tabular}

$*_{\text {figures in the parenthesis are arcsine transformed values }}$ 


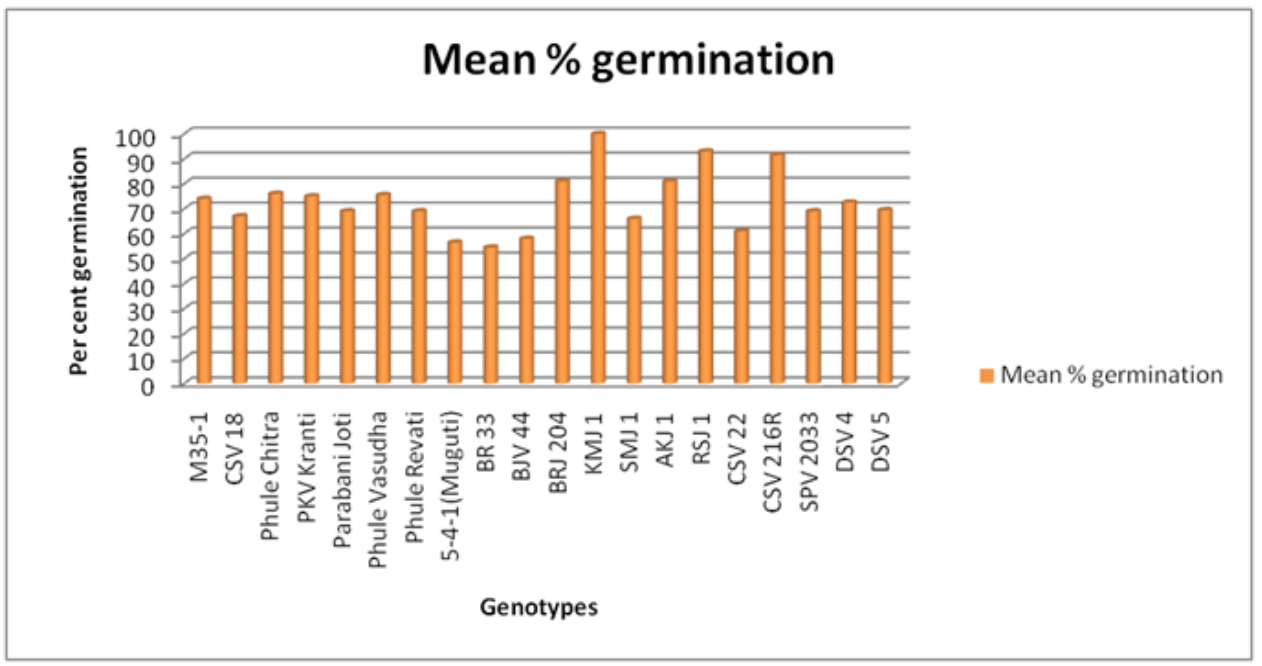

Figure 2A Seed quality as influenced by different genotypes infested by Sitophilus oryzae in sorghum, per cent germination.

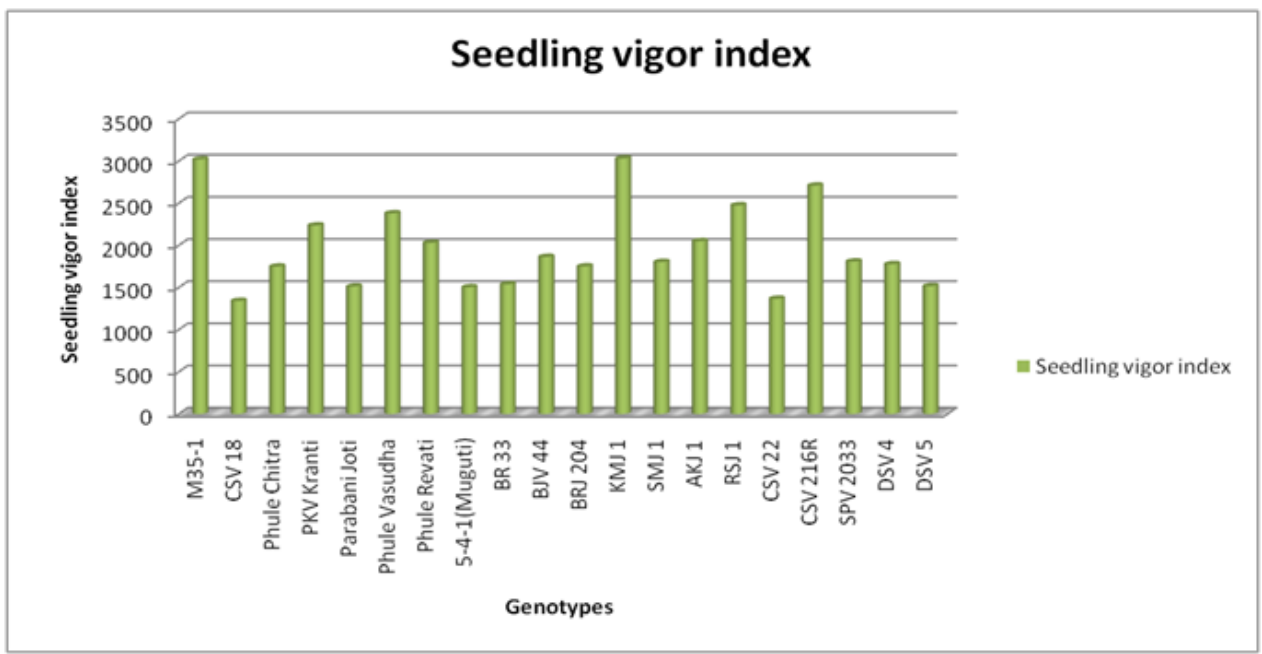

Figure 2B Seed quality as influenced by different genotypes infested by Sitophilus oryzae in sorghum, seedling vigor index.

Seedling vigor index of sorghum in infested condition at I 20 days after storage

The seedling vigor index of the sorghum genotypes under damaged condition are recorded and significantly highest was noticed in the genotype M 35-1(2649), where as the minimum was observed in CSV 18(1005). The rest of the genotypes showed vigor index between the range 1061 and 2530. All the treatments differed significantly with each other.

Correlation between per cent germination to per cent grain damage and per cent population buildup in infested sorghum grains

The data pertaining to the correlation between per cent germination to per cent grain damage and population buildup of rice weevil in sorghum grains in damaged condition infested by $S$. oryzae at 120 days after storage are presented in the Table 4.

The grain damage and population buildup were assumed to one per cent when the grains were in damaged state, the correlation $(r)$ was
-0.49 and -0.54 , indicating that, when there was one per cent increase in grain damage that leads in 0.49 per cent reduction in germination, whereas, there was reduction in germination by 0.54 per cent for every one per cent population buildup of weevils and both the values are significant at 5 per cent.

The investigations are similar with the work of Kudachi ${ }^{5}$ conducted on different genotypes of sorghum and reported that, significantly maximum viability was in RS 585 (78.00\%) followed by BRJ $356(76.50 \%)$ which were on par with each other. The next best genotypes with high viability per cent were CSV 216R, DJ 6514, SPV 489 and IS $18551(65.50$ to $74.00 \%)$. Jadhav ${ }^{6}$ reported that, DSV 3 recorded maximum germination of 69.00 per cent followed by CSH $16(59.80 \%)$ and very poor germination in Shiggaon local $(30.30 \%)$. The variations in the results in present study are due to change in the genotypes included in the study.

The genotypes with higher germination percentage and higher seedling vigor even under rice weevil infested condition can recommended for farmer cultivation in northern Karnataka region of India. 
Table 4 Correlation between per cent germination of sorghum grains to grain damage and population buildup (Infested condition)

\begin{tabular}{|c|c|c|c|c|}
\hline SI. No. & $\begin{array}{l}\text { Varieties/ } \\
\text { Genotypes }\end{array}$ & $\begin{array}{l}\text { Per cent } \\
\text { germination }\end{array}$ & $\begin{array}{l}\text { Per cent grain } \\
\text { damage at I } 20 \text { DAS }\end{array}$ & $\begin{array}{l}\text { Population buildup at } \\
\text { I } 20 \text { DAS }\end{array}$ \\
\hline I. & M 35-I & 74 & 21.2 & 25.5 \\
\hline 2. & CSV 18 & 67 & 37.4 & 29 \\
\hline 3. & Phule Chitra & 76 & 48 & 29 \\
\hline 4. & PKV Kranti & 75 & 50 & 29.5 \\
\hline 5. & Parabani Joti & 69 & 47 & 39 \\
\hline 6. & Phule Vasudha & 75.5 & 49 & 31 \\
\hline 7. & Phule Revati & 69 & 51 & 30 \\
\hline 8. & 5-4-I (Muguti) & 56.5 & 49.45 & 35.5 \\
\hline 9. & BR 33 & 54.5 & 59 & $4 I$ \\
\hline 10. & BJV 44 & 81 & 57 & 32 \\
\hline 11. & BRJ 204 & 58 & 43.3 & 25.5 \\
\hline 12. & KMJ I & 100 & 27.2 & 25 \\
\hline 13. & SMJ I & 66 & 33.9 & 26.5 \\
\hline 14. & AKJ I & 81 & 28 & 24.5 \\
\hline 15. & RSJ I & 93 & 28 & 25.5 \\
\hline 16. & CSV 22 & 61 & 43.2 & 39 \\
\hline 17. & CSV $216 R$ & 91.5 & 36 & 30.5 \\
\hline 18. & SPV 2033 & 69 & 36 & 31 \\
\hline 19. & DSV 4 & 72.5 & 36 & 31 \\
\hline \multirow[t]{2}{*}{20.} & DSV 5 & 69.5 & 38.7 & 35 \\
\hline & \multicolumn{2}{|c|}{ Correlation value(r) } & $-0.49 *$ & $-0.54 *$ \\
\hline
\end{tabular}

DAS, days after storage

*significant at $5 \%$

\section{Acknowledgments}

None.

\section{Conflict of interest}

The author declares no conflict of interest.

\section{References}

1. Venkat Rao S, Nuggenhalli RN, Swaminathan N, et al. Effect of insect infestation on stored grain-III. Studies of insect pests on stored grains. $J$ Sci Food and Agric. 1958;9:837-839.

2. Reddy UK, Pushpamma P. Effect of insect infestation and storage on the nutritional quality of different varieties of pigeon pea. Proc. Int. Workshop on Pigeonpea, Patancheru, Andhra Pradesh, India: ICRISAT 1980. p. 451-453.
3. Anonymous. International Rules for seed testing. Seed Sci Tech. 1996;29:1-3.

4. Abdul- Baki A, Anderson JD. Vigor determination in Soybean seed by multiple criteria. Crop Sci. 1973;13(6):630-633.

5. Kudachi DC. Management of lesser grain borer, Rhizopertha dominica Fab. and rice weevil, Sitophilus oryzae Linn. in stored sorghum. M. Sc. (Agri.) Thesis, Dharwad: Univ Agric Sci; 2008.

6. Jadhav K. Biology and management of Rice weevil, Sitophilus oryzae (L.) in pop sorghum. M. Sc. (Agri.) Thesis, Dharwad: Univ Agric Sci; 2006. 